\title{
26. Bir Halvetî eseri olan Vesile-nâme’nin dil incelemesi
}

Feriştah Funda ARI ${ }^{1}$

APA: Arı, F. F. (2021). Bir Halvetî eseri olan Vesile-nâme'nin dil incelemesi. RumeliDE Dil ve Edebiyat Araştırmaları Dergisi, (24), 487-497. DOI: 10.29000/rumelide.995353.

$\ddot{\mathbf{O} z}$

Dil, insanla birlikte ortaya çıkmış, onunla birlikte büyümüş, gelişmiş ve değişmiş, hatta dünyadaki pek çok dil de konuşucusuyla birlikte yok olmuştur. Bir milletin kültürü, o milletin diliyle yakından ilişkili ve milli kimliğin belirleyici unsurlarının başında gelir. Şeyhoğlu Derviş Osman tarafindan yazılan Vesīe-nâme, 18. yüzyılda kullanılan Türkçenin, özellikle dönemin konuşma dilinin, daha iyi anlaşılabilmesine katkı sağlamak amacıyla dil incelemesi yapılmıştır. Vesīle-nâme adlı eser, Klâsik Osmanlı Türkçesi döneminin nesir türünde yazılmış, dinî-didaktik bir metindir. Eserin tespit edilen tek nüshası Koç Üniversitesi Dijital Koleksiyonlar bölümünde bulunmaktadır. Eserde Arapça ve Farsça kelime ve terkiplerin yanında, ayet ve hadisler de yer almaktadır. Ayrıca hikâyeler, atasözleri, deyimler ve metin genel itibariyle konuşma dili kullanılarak yazıldığı için sade ve akıcıdır. Genellikle damak uyumu görülmesine rağmen, aykırı durumlar da mevcuttur. 18. yüzyılda dudak uyumuna giren ve/veya girmeye başlayan sözcüklerin bulunması, Türkiye Türkçesine yönelen bir sürece girmeye başlamış olduğunun da göstergesi kabul edilebilir. İmla, ses bilgisi ve biçim bilgisi incelendiğinde oldukça zengin bir içeriğe sahip olan Vesīle-nâme, bugüne kadar çalışılmamıştır. Bu çalışmada Vesīle-nâme'nin dil incelemesi hakkında bilgiler verilmeye çalışılacaktır.

Anahtar kelimeler: Vesīle-nâme, Osmanlı Türkçesi, damak uyumu, dudak uyumu, imla (yazım)

\section{Linguistic analysis of Vesịle-nâme which is a work Halvetism}

\begin{abstract}
Language emerged with man, grew, developed and changed with him, and even many languages in the world disappeared with their speakers. The culture of a nation is closely related to the language of that nation and even comes first among the determining factors of national identity. Vesīe-nâme, written by Şeyhoğlu Derviş Osman, has been studied in order to contribute to a better understanding of the Turkish used in the 18th century, especially the spoken language of the period. Vesile-nâme is a religious-didactic text written in the prose genre of the Classical Ottoman Turkish period. The only detected copy of the work is in Koç University Digital Collections department. In addition to Arabic and Persian words and compounds, verses and hadiths are also included in the work. In addition, the language of the text is simple and fluent, as religious stories, proverbs, idioms and text are generally written using colloquial language. Although palate harmony compatibility is generally observed, there are also contradictory situations. In the 18th century, the presence of words that entered into lip harmony and/or began to enter can be accepted as an indication that Turkey started to enter a process that turned to Turkish. Vesile-name, which has a very rich content when examined in terms of spelling, phonetics and morphology, has not been studied until today. In this study, it will be tried to give information about Vesile-name's language analysis.
\end{abstract}

Doktora, Uludağ Üniversitesi, Fen Edebiyat Fakültesi, Sosyal Bilimler Enstitüsü, Türk Dili ve Edebiyatı ABD (Bursa, Türkiye), feristah.uysal@hotmail.com, ORCID ID: oooo-0002-3959-3769 [Araştırma makalesi, Makale kayıt tarihi: 16.07.2021-kabul tarihi: 20.09.2021; DOI: 10.29000/rumelide.995353]

Adres $\mid$ Address

RumeliDE Dil ve Edebiyat Araştırmaları Dergisi $\quad$ RumeliDE Journal of Language and Literature Studies Osmanağa Mahallesi, Mürver Çiçeği Sokak, No:14/8 $\quad$ Osmanağa Mahallesi, Mürver Çiçeği Sokak, No:14/8

Kadıköy - ÍSTANBUL / TÜRKIYE 34714 Kadıköy - ISTANBUL / TURKEY 34714 e-posta: editor@rumelide.com e-mail: editor@rumelide.com, tel: +90 505 7958124, +90 2167730616 phone: +90 505 7958124, +90 2167730616 
Keywords: Vesīle-name, Ottoman Turkish, palate harmony, lip harmony, spelling

\section{Giriş}

Dil, bir milletin olmazsa olmaz en önemli unsurlarındandır. Ayrıca kendine ait kuralları bulunan ve bu kurallar çerçevesinde gelişen canlı bir varlık olan dil, milli kültürün temel taşlarındandır. Türk dili zaman içinde, çeşitli sebeplerle alfabesini, dinini ya da bir takım kültürel unsurlarını değiştirmek durumunda kalmıştır. Bu değişimleri yaşayan Türkçenin eski dönemlerden çeşitli alfabelerle yazılmış eserlerinin günümüze ulaştırılması ve bir nevi köprü görevi görülmesi için, pek çok bilim insanı çalışmış ve hala çalışmaktadır. Bu çalışma da eseri günümüze ulaştırmanın yanında eser aracıllğıyla yazıldığı döneme ve Türk diline ait özellikleri ortaya koyma amacıyla gerçekleştirilmiştir.

XV. yüzyll ve XX. yüzyll arasındaki zaman dilimi 'Klâsik Osmanlı Türkçesi' (Ercilasun, 2016: 457; Akar, 2005: 287) ya da 'Yeni Türkçe devri' (Caferoğlu, 2001: 52) olarak adlandırllır. Vesile-nâme, Türkçenin XVIII. yüzyılda yaşadığı değişim ve gelişimleri, özellikle Türkçenin konuşma dilinde kullanılan biçimini, örneklendiren bir metindir. Ancak Vesile-nâme, bu dönemde Osmanlı Türkçesiyle yazılan diğer eserlerde olduğu gibi, gerek Arap harflerinin Türkçe ses özelliklerini tam olarak yansıtmaması, gerekse alıntı kelimelerin fazlalığından kaynaklı tutarsız örnekleri barındırır. Bunun yanında, metin içerisinde imla kalıplaşmasının düzensizliği dikkati çeker. Ayrıca bu döneme kadar yapılan metin çalışmalarında standartlaşmamış olan dudak uyumu, XVIII. yüzyılda büyük oranda tamamlanır (Kartallığlu, 2011: 11). Vesīle-nâme'de de bu durum teyit edilir.

\section{Vesīle-nâme'nin konusu}

Vesīle-nâme yedi fasıl üzerine düzenlenen dinî-didaktik bir metindir. İlk faslında dört halifeden ve bunların kaç yıl halifelik yapıp, nasıl şehit edildiklerinden bahsedilir. İkinci fasılda, Hz. Ali'nin nesli ve bu neslin Yezid tarafından katledildiği anlatılır. Üçüncü fasılda, Allah, Peygamber, şeyh, halifeler gibi mübarek zatlar anıldığında, her biriyle ilgili farklı saygı, dua ve yüceltme ifadelerinin eklenmesi gerektiği salık verilir. Dördüncü fasılda insan-ı kâmil ve insan-ı kâmil mertebesine yükselmek için yapılacaklar açıklanır. Beşinci fasılda, müridin mürşide, mürşidin şeyh-i kâmile davranışları anlatılır. Altıncı fasılda, mümin müminin kardeşidir, düsturundan hareketle kardeşliğin koşulları açılanır. Yedinci ve son fasılda ise, dervişlik ve sūfîlik konu edilir. 'Sūfî' kelimesinin, her bir harfinin, tarikata göre ifade ettiği anlamlar izah edilir.

\section{Yazım özellikleri}

Osmanlı Türkçesi, Osmanlı Devleti'nin hakimiyet sınırları içinde bulunan, 15. yüzyıldan itibaren standartlaşmaya başlayan ve Arap harfleriyle yazılan Türk dilinin önemli eserlerinin yer aldığı dönemdir (Demir ve Yllmaz, 2002: 475-488). Daha önce incelenen eserlerde, 17. yüzylla kadar Osmanlı Türkçesinin standart dil uyumlarının yanında Eski Anadolu Türkçesi özelliği bulunan kelimeler ve ekler de görülmektedir; ancak özellikle 17. ve 18. yüzyıllarda imla kuralları ve diğer dil özelliklerinin standartlaştı̆̆ı belirtilir (Gökçe, 2009: 991-1012). 18. yüzylla ait olduğunu, müellifi sayesinde, tespit ettiğimiz Vesile-nâme adlı bu çalışmada ise sıkça Türkçenin konuşmada kullanılan biçimine yer verildiği görülmekte; çünkü bazı kelimeler sözlükteki aslından farklı yazılmış, harekeler sayesinde okunan kelimelerin de dönemin konuşma dili söylenişine göre yazıldığı tespit edilmiştir. Bunun dışında aynı kelime aynı metinde iki farklı şekilde yazıldığı gibi bir de Uygur imlası özelliklerinden biri olarak ünlüler gösterilmiştir. Hem Uygur hem de Arap-Fars imla özelliği gösteren bu metnin, özellikle bazı yerlerde,

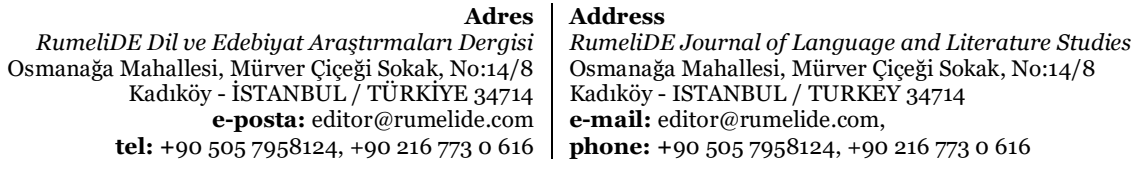


ünlülerin yazılmama sebeplerinin hareke kullanımı olduğu da düşünülmektedir (Şahin, 2003: 33). Ayrıca metnin okunmasında harekeler oldukça yol gösterici olmuştur. Ayrıca 18. yüzyılda kullanılan eklerin kullanımı da metnin anlaşılmasında oldukça etkili olduğu söylenebilir. Bunun yanında sözcüklerin ekleri incelendiğinde aynı ekin hem düz hem de yuvarlak biçimi bir arada kullanıldığ görülür. Bu durum aynı zamanda dönemin konuşma dilinin özelliğinin metne yansıması olarak düşünülmektedir. Eski Anadolu Türkçesinde yuvarlak ünlülü kullanılan bazı eklerin Vesīle-nâme'de yuvarlaklı̆̆ını koruduğu da görülmüştür.

Örnek: -dUK eki, cümlede bu ekten önce kullanılan özneler bazen yazılmayabilir; fakat -DIK / -DUK eki üzerine gelen iyelik ekleri fiilin öznesiyle ilişki kurarlar (Gülsevin, 2015: 890). Eski Türkçe ve Eski Anadolu Türkçesinde, bu ek, daima yuvarlak ünlülüdür; fakat 18. yüzyll Osmanlı Türkçesi metinlerinde ekin yuvarlak şekillerinin yanında düz şekilleri de görülmektedir (Kartallığlu, 2011: 237). Vesīenâme'de ise -dUK sıfat-fiil ekinin düz ünlülü şekline rastlanmamıştır. Bu ekin kullanımında vav (و) harfi gösterildiği gibi, harf gösterilmeyip sadece ötre (و) harekesiyle de gösterildiği kelimeler de vardır.

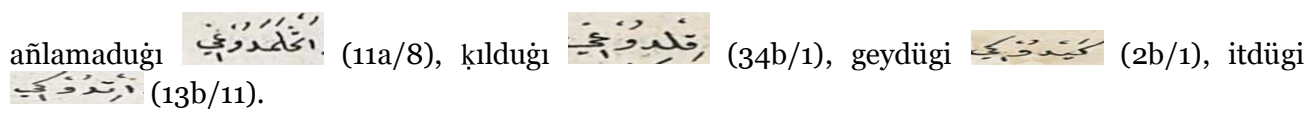

+DUr bildirme eki, ad ve ad soylu sözcükleri yüklemleştiren +DIr ve +DUr eki, er- cevher fiilin geniş zaman (şimdiki zaman) 3. kişilerde kullanılmıştır (Savran, 2008/1: 184; Ediskun, 2017: 175). Vesīlenâme'de ek, vav (و) harfi hiç kullanılmamıştır; fakat harekeli bir metin olan metin bu eki ötre (و) harekesi ile harekelendirildiği için yuvarlak ünlülü okunmuştur.

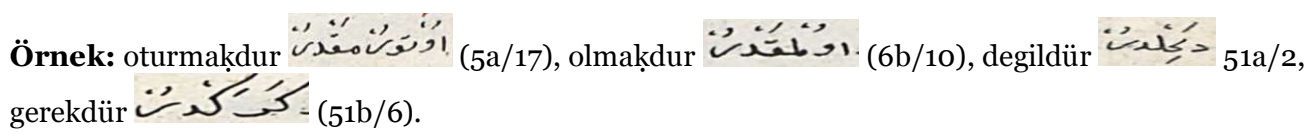

Metinde sadece dört kelimede esre ( ) ) ile gösterilen ekler dar ünlülü okunmuştur.

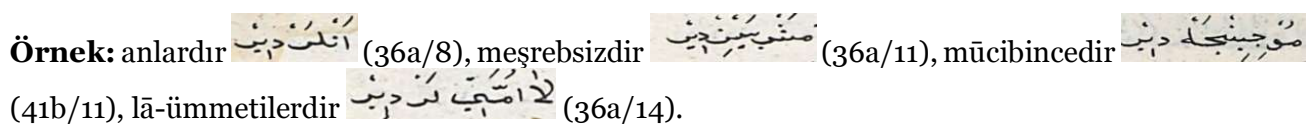

\section{Dönemin konuşma dili}

Vesile-nâme adlı eserin en önemli özelliklerinden biri kaleme alındığı dönemin konuşma dilini yansıtmasıdır. 18. yüzyıl hatta Osmanlı Türkçesi eserleri göz önüne alındığında genel itibariyle yazı dilinin esas alındığı görülürken Vesỉle-nâme'de, gerek aynı kelimenin aynı metin içerisinde farklı yazılması (eren 6b/6-eren آَرَان 2a/8), gerek eklerin geçiş dönemi olmamasına rağmen hem düz hem

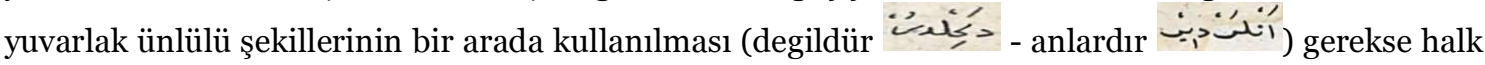
ağzında kullanılan ve Derleme Sözlüğünde de bulunabilen kelimelerin kullanılması (köşek 1b/8) dönemin konuşma dilini yansıttığının göstergeleri olarak kabul edilebilir. Aynı kelimenin aynı metinde farklı yazılması müellif ya da müstensih veya müellifin direktifiyle yazan kâtibin hatası olarak da kabul edilebilir. Ancak bunların kesinliği hakkında bir bilgi mevcut olmadığından ve belirtilen sebeplerden dolayı konuşma dilinin etkisinin olduğu daha kuvvetle ihtimaldir.

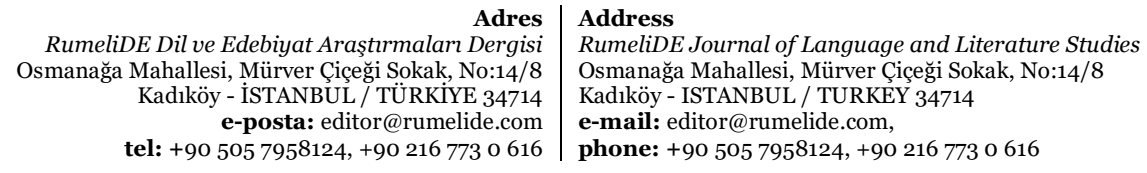




\section{Ses bilgisi}

Ses bilgisi, dilin her düzleminde görülen seslerin yapıları, ses kuralları kadar, bu seslerdeki değişmeleri de inceler. Ses bilgisi hem biçim bilgisiyle hem de cümle bilgisiyle ilişkilidir; çünkü sözlerde görülen biçim bilgisi ve söz dizimi özellik ve değişiklikleri, sözlerin ses yapılarıyla doğrudan ilişki içindedir (Karaağaç, 2013: 645). Bununla beraber dildeki seslerin birleşme ve değişimlerini de incelemektedir. Ancak Arap harfli metinlerde Türkçe kelimelerin ses bilgisini tespit etmek zordur. Buna rağmen imla üzerindeki değişimler ve ikili kullanımların yaygınlı̆̆ına göre belirlenmesi durumuna göre okuma yapılabilmektedir.

Vesīe-nâme adlı bu eserde bulunan kelimeler, fonetik hadiselere ve ikili kullanımlarına göre örneklendirilmiştir. Ünlü ve ünsüz seslerin durumu ayrı ayrı incelenerek Türk dilinin 18. yüzyıldaki fonetik durumu gösterilmeye çalışlmıştır.

\subsection{Damak uyumu}

Bu uyum söz içinde ünlüleri ince (ön) ve kalın (art) sıraya göre ayarlayan; Eski Türkçeden beri gelişmiş bir şekilde görülen (Şahin, 1993: 53); bu nedenle Osmanlı Türkçesi metinlerinde de neredeyse tam olarak karşlaşılan bir özelliktir. Türkçenin temel ses uyumu (Gülsevin, 2004: 93) olarak görülen kalınlık-incelik uyumu, Karaağaç’a göre de Türkçede istisnası hiç bulunmayan en büyük ses uyumudur (Karaağaç, 2013: 263). Türkçe kelimelerde var olan damak uyumu, Vesỉe-nâme'de bazı örnekler dışında genel olarak görülmektedir. Ancak aykırı durumlar da söz konusudur. -ken ve -ki gibi bazı ekler, uyumu bozan eklerdendir.

Örnek: ḳarnımdayken 10a/5, arasındaki 19b/7, șāġındaki 33a/15

Vesīe-nâme'de bazı damak uyumuna aykırı olan Türkçe kelimeler şöyledir:

Örnek: itduk 15a/2, gitdüğından 55a/5, șāġındaki 33a/15, sütlüğı 35b/8

Vesile-nâme'de yer alan bu aykırı kullanımlar hem J. Eckmann (Eckmann, 2013: 13) ve Ahmet Cevdet Paşa'nın belirttiği gibi müstensih tarafından yapılan bir hata (Karabey ve Atalay, 2017: 7) hem de dönemin ağız özelliklerinin metinde yansıtılması olarak düşünülebilir. Bu örnekleri Batı Türkçesinin fonetik gelişim sürecine göre ve ağızlar şeklinde çeşitlenmesine tanıklık eden şahitler olarak ele alınırsa (Duman, 2004: 793) Türkiye Türkçesinin belirlenmesinde de önemli veriler olarak değerlendirilmelidir (Develi, 1995: 25-27).

Alıntı kelimelerde örnekler: keşfilıgı 35b/4, helāklik 33a/10, şeyḩlık 15a/15, selāmetlığıla 16b/12

\section{2. Dudak uyumu}

Günümüze kadar oldukça yavaş ilerleyen bir uyum olan dudak uyumu, Eski Türkçede tam değildi (Şahin, 1993: 53). "Bu uyumsuzluğun sebeplerini iki grupta toplamak mümkündür: Illki Eski Anadolu Türkçesi döneminde bir hayli ilerlemiş olan 'yuvarlaklaşma', ikincisi ise 'düzleşme' hadisesidir. Bu iki önemli sebebe Eski Türkçe döneminden itibaren düz ya da yuvarlak ünlülü olarak görülen kelime ve ekler de dâhil edildiğinde, Türk dilinin tarihî dönemleri içinde dudak uyumunun en zayıf olduğu dönem olarak karşımıza çıkar" (Gökçe, 2009: 993). Klâsik Osmanlı Türkçesi döneminde ise bu uyumun 18. yüzyılın sonlarında tamamlandığı düşünülmektedir (Develi, 1995: 60).

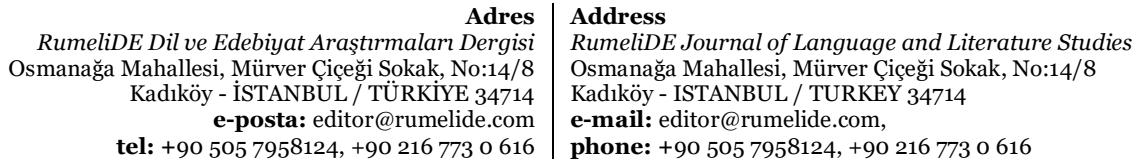


Örnek: ḳapusı 22b/9, getürdi 23a/6, girü 25b/8, eyü 28b/12

Vesile-nâme'de dudak uyumunda ikili kullanımlara örnek de bulunmaktadır: yıldız 4b/13 - ylduz 4b/10, kendi 30a/15 - kendü 30a/17.

-(y)AlUm/ -(y)AvUz istek kipi 1. çoğul kişi eki: Fiilin ifade ettiği hareketin istek yoluyla tasarlandığını anlatan bu ek (Şahin, 2003: 62), Vesile-nâme'de 6 kelimede vav (و) harfi yazılmış olmasının yanısıra 12 kelime de sadece ötre (و) kullanılarak yazılmış ve vav (و) harfi gösterilmemiştir.

Örnek: olmayalum 1ob/4, itmeyelüm 10b/2, girelüm 1b/9, açalum 24b/15

-vUz eki vav (و), elif (') ve ze (j) harfleriyle gösterilmesinin yanında ötre (-) ile gösterilmiştir. Vesilenâme'de bir örnekte görülmektedir.

Örnek: yolundan dönmeyevüz 43a/10-11

\section{3. Ünsüzler ve ünsüz uyumu}

Ünsüz, ă̆ız kanalında ve diğer ses organlarında bir engelleme, daralma veya kapanmayla ve bir ünlü yardımıyla çıkarılan sestir (Korkmaz, 2017: 242). Vesile-nâmede tespit edilen ünsüzler şunlardır: b, c, ç, d, f, g, ġ, h, ḥ, h, k, k, l, m, n, ñ, p, r,s, ș, șs,s, t, ț, v, y, z, z, ż, z.

Ünsüzler arasındaki bir ötümlülük-ötümsüzlük uyumu ünsüz-ünsüz uyumudur ve Türkçede ötümlü ünsüzler, ötümlü ünsüzlerle; ötümsüz ünsüzler de ötümsüzler veya ötümsüz karşllğı bulunmayan ötümlüler, yani sürtünmesizler ile yan yana bulunabilir (Korkmaz, 2017: 818). Metinde geçen ötümlüler: b, c, d, v, g, g, z; ötümsüzler: p, ç, t, f, h, h, h, k, k, s, ş; sürtünmesizler: l, m, n, ñ, r, y. Klasik Osmanlı Türkçesinde de Eski Türkçe ve Eski Anadolu Türkçesinde olduğu gibi Türkçenin eski dönemlerinden itibaren ötümlülük-ötümsüzlük uyumu görülmemektedir. Bu dönemdeki Arap harfli metinlerde kelimelere yeni ekler getirildiğinde genellikle tonlu ünsüzler kullanıldı̆̆ından ünsüz uyumunu tespit etmek zordur. Ötümlü şekilleriyle kalıplaşmış olan ekler kelimenin kök veya tabanı ötümsüz bir ünsüzle de bitse her zaman ötümlü olarak kullanılırlar (Şahin, 2003: 41).

Örnek: +dA bulunma (locative) durum eki: ortasında 1b/2, dükḳanında 1b/10, meydānında 2a/7, altında $3 \mathrm{~b} / 17$, kitābında $37 \mathrm{~b} / 11$, anda $41 \mathrm{a} / 3$

+dAn ayrılma (ablative) durum eki: anlardan 48a/9, kāirlerden 48b/13, gözinden 5o/11, yoldan $52 \mathrm{a} / 15$, nefsinden $46 \mathrm{~b} / 5$, şübhelülerden $47 \mathrm{~b} / 6$.

-dI görülen geçmiş zaman 3 . tekil kişi ekleri: yatdı 1b/4, ayırmayalardı 2a/11, virdi $2 b / 7$, dimedi 4a/16, uggrardı 29a/15, yazıldı 30a/7.

-dIlAr görülen geçmiş zaman 3. çokluk kişi eki: geçdiler 18a/15, işitdiler 21b/10, ayıtdılar $35 \mathrm{a} / 4$, çıłardılar 38a/4, kefinlediler 24b/10, güldiler $25 \mathrm{a} / 3$.

+dUr bildirme eki: tācdur 2b/8, hațādur 2b/11, köşekdür 1b/8, degildür 2a/4, birdür 31a/11, kişidür $33 \mathrm{~b} / 8$.

+dUr çatı eki: aydurdı 29a/11, ḳldurur 28b/6, bildürelüm 2a/16, yetişdürelüm 2b/11, indürmekdür $5 \mathrm{a} / 6$, geydürür $5 \mathrm{~b} / 2$.

+dUm görülen geçmiş zaman 1. tekil kişi: buldum $8 \mathrm{a} / 16$, dimedüm $9 \mathrm{a} / 1$, ḳodum $9 \mathrm{~b} / 6$, itdüm 12a/1, eyledüm 12a/9, uçdum 9b/11.

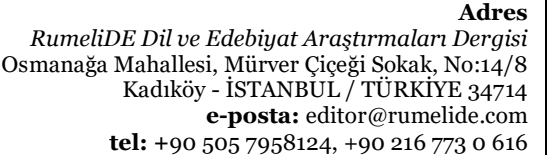

dres

(1)

RumeliDE Journal of Language and Literature Studies

Osmanağa Mahallesi, Mürver Çiçeği Sokak, No:14/8

Kadıköy - ISTANBUL / TURKEY 34714

e-mail: editor@rumelide.com,

phone: +90 $5057958124,+902167730616$ 


\section{Fonetik hadiseler}

Her dilde olduğu gibi Türkçede de sesler çok fazla ama belli sesleri gösteren harfler sayılıdır. Sesler, dilin çeşitlilikleriyle fark edilir. Dil, canlı ve değişken bir yapıya sahiptir. Fonetik hadiseler de dilin bu yapısını ve zamanla gösterdiği çeşitliliği sergiler. Vesile-nâme'de bu hadiseler ötümlüleşme (doḳuzuncı 10a/13, dilde 2a/3), ötümsüzleşme (eşid-diler > işitdiler 21b/10), sızıcılaşma (bar > var 34a/16, seb- > sev53a/8), erime (tirig > diri 36b/1), yutulma (edgü > eyü 28b/14), dudaklılaşma (bıçık > buçuk 21a/9), düşme (uş imdi > şimdi 28b/4, bol- > ol- 4ob/13), türeme (üçinç > üçinci 15b/7), ikizleşme (1sı̀g > 1ssı 8b/13), tekleşme (oltur- > otur- 5a/16), hece düşmesi (taşık- >> çık- 51b/13), geçişme (ne içün > niçün 34b/12), birleşme (țoḳuz on > țokssan 41a/4), ünsüz kaynaşması (senge > saña 17b/5) ve darlaşma (yorı>> yürü- 52a/5) başlıkları altında incelenmiştir.

\section{Biçim bilgisi}

Bir dildeki asıl ve bağlı biçim birimlerini, bunların kullanım yollarını, bağlı biçim birimlerinin anlam ve görevlerini, dilin üretme ve çekim özelliklerini ve biçimle ilgili öteki konuları inceleyen dil bilgisi dalına biçim bilgisi denir (Karaağaç, 2013: 191). Kelime kökleri ve gövdelerine gelerek yeni kelimeler üretmek için kullanılan yapım ekleri ile kelimelere geçici olarak eklenerek kelimeler arasında çeşitli anlam ilgisi kuran çekim ekleri biçim bilgisinin temel yapı taşlarıdır (Aydın, 2019: 63).

Vesīle-nâme incelemesinin bu bölümünde Gürer Gülsevin’in “Türkçede Siradışı Ekler ve Eklerin TasnifTanımlama Sorunu Üzerine" (Gülsevin, 2004: 1276) adlı bildirideki düzen dikkate alınmaya çalışılmıştır.

\section{1. Yapım ekleri}

Ad ya da fiil kök ve gövdelerinden yeni ad ya da fiil gövdeleri yapan ekler yapım ekleridir. Kelimenin sonuna bir ya da birden fazla ekin getirilmesiyle meydana gelmiş şekilleri teşkil etmektedir (Arat, 1955: 398). "Yapım ekleri kök ve gövdenin kendi sınırları içinde kaldığı hâlde, işletme ekleri, kök ve gövdelere bazı anlam bağlantıları katarak onları birbiriyle ilişkiye geçiren, onlarla kelime grupları ve cümlenin öteki ögeleri arasında geçici anlam örgüsü kuran eklerdir” (Korkmaz, 2017: 110). Türkçenin kelime hazinesi bakımından önemli bir yer teşkil eden bu ekler dörde ayrılır:

a) İsimden isim yapan ekler

Örnek: yoldas 28b/17, ilerü 4ob/15, Resūlüñ ulu sevgülü yārenleridür 21a/1, uyanıḳlḳ 35a/11

b) İsimden fiil yapan ekler

Örnek: beñze- 4b/16, alda- (al+da-) 15a/16, yükle- 31a/2

c) Fiilden isim yapan ekler

A. Fiilimsiler

a. Mastarlar

Örnek: nās yazduğı mahlūk yazmasıyla 3oa/16, yitdügi yirden dem urmak gerekdür 44b/9

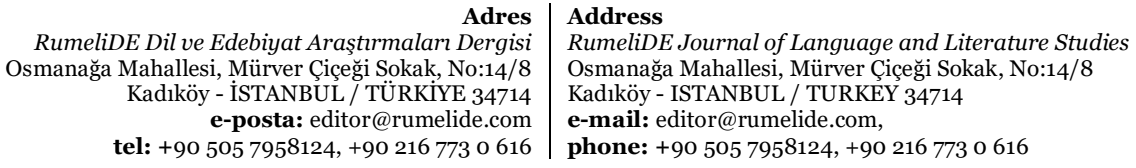


b. Partisipler (sıfat-fiiler / ortaç)

Örnek: şol yabanda aḳan șular 48a/5, eger yaramaz yoldaş ise 28b/14, her kişi ḳatına geldügi vaḳit $15 \mathrm{~b} / 9$

c. Gerundiumlar (zarf-fiiller / ulaç)

Örnek: țālibüñ mertebesi artdukça şeyḥüñ dahı artar 45a/9-10, boynuna bırağup geydürmek 6a/4, halfe olıcak anlarunla çekişmedi 23b/2, veliyyete irmeyince kişi veli olmaz 39b/15

\section{Hâl ekleri}

Adın cümle içinde bulunduğu dil bilgisi şekli; yalın ya da yükleme, yönelme, bulunma, ayrılma, vasıta ve eşitlik ekleri alarak genişletilmiştir. Türkçede işlek kullanılan işletme ekleridir. Bir cümlenin anlaşılabilir olması için, cümlede geçen hâl ekinin gerçek fonksiyonuyla kullanılması gerekmektedir. Eğer bir cümlede geçen hâl eklerinden biri gerçek fonksiyonu ile anlaşılamazsa, o cümleye verilen anlam da yanlış olur (Gülsevin, 2020: 25). Özellikle yazı dili cümleler halinde incelendiğinde hâl eklerinin işlevini tespit etmek oldukça zordur.

Vesīe-nâme'de hâl ekleri Fundamenta'da verilen sıraya [Nomative (ș tobrak keşfidür 35b/6-7), Accuzative (bunı dahı hiç kimse meni‘ itmez 32a/3), Dative (şol mertebeye irdi 8b/14), Locative (evde ḳapanup 8a/7), Ablative (cennetden ab-1 hayāt getürdi 24b/4), Instrumental (mü'min kullarıyla müzeyyịn ḳıldı 12b/6), Equative (sinsilesi sahihçe 'Alịye ve Muḥammede yıḳa 15b/14)] göre incelendi. Bütün hâl ekleri bir isim ile bir fiil arasında ilişki kurmasına rağmen genetive eki yalnızca bir isimle başka bir isim arasında ilgi kurduğu için bu ek hâl ekleri başlığı altında verilmedi. Genetive eki çok sınırlı alanlarda isimle fiil arasında bağlantı kuruldu ancak bu tip örnekler incelendiğinde genetive ekinin isimle fiil arasında ilgi kurmadığını, bu kullanımların aslında bir tamlamanın kısaltılmışs şekli olduğu görülebilir (Şahin, 1993: 99).

\section{Fiil çekimi}

Fiil çekimi ekleri fiil kök ve gövdelerindeki hareketleri kişi ve nesnelere bağlamak, adlarla fiiller arasında geçici anlam ilişkileri kurmak için başvurulan eklerdir.

Fiil çekiminde, bir fiil köküne sırasıyla, görünüş, zaman-kip, kişi ve çokluk ekleri gelir. Emir kipinin teklik ikinci kişisi dışındaki tüm durumlarda fiiller ancak belli ekleri alarak cümle içinde bulunabilirler; fakat emir kipi ek almaz, fiil kök ya da gövdesiyle yapılır (Demir ve Yılmaz, 2003: 187). Fiil çekimini ve bu çekimde kullanılan eklerin yazılı bir metinde işlemekteki zorluklardan biri de özellikle vurgu ve tonlamanın eklere fonksiyon yüklemede son derece etkili oluşudur.

Vesīe-nâme'de fiillerin çekimi ‘basit’ ve ‘birleşik' çekim olarak incelenmiştir.

\section{1. Basit çekim}

Bildirme ya da tasarlama kiplerinden sadece birinin olduğu fiil çekimidir.

\section{1. 1. Bildirme kipleri}

Gerçekleşmiş, gerçekleşen ve gerçekleşeceğini düşündü̆üümüz iş, olay ve durumları anlatabilmek için kullanılan kiplerdir.

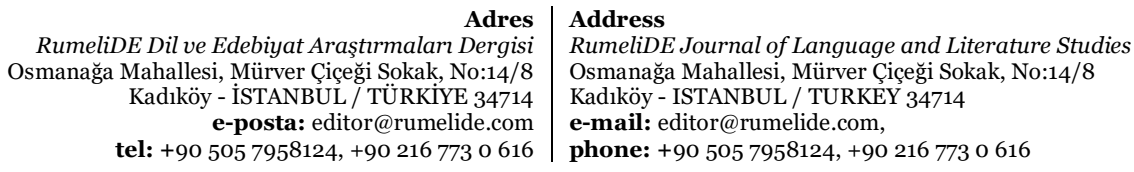




\section{1. 2. Tasarlama kipleri}

"Eylemin olumlu ya da olumsuz yönde gerçekleşmesini, tasarlanan dilek, istek, şart, gereklilik veya emir kavramları içinde ve herhangi bir zaman değil, yalnızca görünüş veren kipler oluşturur” (Karaağaç, 2013, s. 795). Bu kiplerin zamanlara göre değil, işlevlerine göre adlandırılmalarının nedeni de böyle açık bir zaman gösterme özelliği taşımamalarındandır. Bu yüzden tasarlama kiplerini 'yardımcı zamanlar' başlı̆̆ı altında değerlendiren H. Zülfikar gibi bazı dilciler de vardır (Zülfikar, 1969, s. 125).

Tasarlama kiplerinde zaman kavramını belirtmek için genellikle zarflara başvurulur. Bazen bu durum, metnin bağlamı içinde başka sözlerle de ayarlanabilir (Korkmaz, 2017: 577).

"Emir, istek, gereklilik kiplerinin farklı görevlerde kullanılması ancak,

a. Cümledeki diğer kelimelere,

b. Cümledeki kişiler arasındaki duygusal ve hiyerarşik ilişkilere,

c. Vurgu ve tonlamaya,

ç. İsteğin gerçekleşmesi için gereken zamana,

d. İsteğin derecesine gibi konularda ayrılıklar göstermektedir.” (Şahin, 1993:145)

Bu kipler, herhangi bir zaman belirtmedikleri için anlamlarına göre adlandırılırlar.

\section{1. 2. 1. İstek kipi}

Fiile istek, niyet, arzu kavramları veren bir tasarlama kipidir. Yapılan hareketin istek şeklide ifade eden veya o işe niyet edildiğini gösteren kip ekidir.

Örnek: çün ben ölem 24a/8, saña varayın 23b/14, acıġa azacık yiye karnı doyunca yimeye 48a/16

\section{1. 2. 2. Emir kipi}

Tasarlanan hareketin yapılmasını emir şeklinde ifade eder. 1. kişi için emir çekimi yoktur. Vesīlenâme’de 2. kişi için -gIl ekine rastlanmamıştır.

Örnek: andan bize söyle 9b/17, tābūdile alsun gitsün 24a/10, ey aṣhạbım bilüñ $6 \mathrm{~b} / 13$

\section{1. 2. 3. Gereklilik kipi}

Belirli bir zamana girmeyen, fiilin gösterdiği oluş ve kılışın yapılması gerekli olduğunu bildiren (Korkmaz, 2017, s. 143) ektir. Vesile-nâme'de şart ve mastar ekine 'gerek' sözcüğünün eklenmesiyle gereklilik kipi oluşturulmuştur.

Örnek: hạkü̈m itse gerekdür 18a/3, terk itmek gerekdür 47a/17

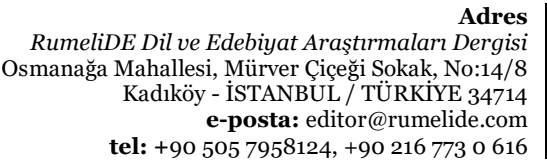

RumeliDE Dil ve Edebiyat Araştırmaları Dergisi Kadıköy - İSTANBUL / TÜRKIYE 34714 tel: $+905057958124,+902167730616$
Address

RumeliDE Journal of Language and Literature Studies

Osmanağa Mahallesi, Mürver Çiçeği Sokak, No:14/8

Kadıköy - ISTANBUL / TURKEY 34714

e-mail: editor@rumelide.com,

phone: +90 $5057958124,+902167730616$ 


\section{1. 2. 4. Dilek-şart kipi}

Hareketin şart şeklinde tasarlandığını, şart olarak düşünüldüğünü anlatmak için fiil kök ve gövdelerine şart eki eklenir (Ergin, 2002: 309). -sA eki ile kurulur.

Örnek: eger ben düșersem ziyānım dahı olur 52a/11-12, misk koysañ dahı 55a/6-7, kim islerse hakịkatile işleye $19 \mathrm{~b} / 16-17$

\section{2. Birleşik çekim}

Bir fiil üzerine iki kip eki aldığında birleşik çekim oluşturur. Kaynaklarda "Birleşik Zamanlı Fiil” olarak adlandırılmasının daha uygun olduğu görüşü belirtilmiştir (Gülsevin, 1997: 215-224). Çünkü tek zaman kavramını üzerinde barındırmasından dolayı "Birleşik Zamanlı Fiil" ifadesi yerine "Birleşik Çekim" olarak adlandırılmasıdır. Birleşik çekimler hikâye, rivayet ve şart çekimi olarak üçe ayrılır.

\section{Örnek:}

Ḥaḳ Te`ālā benim göñlündegin bilürdi $9 \mathrm{~b} / 7$

bu bende[y]i sebeb düşürmișdür $\quad 51 \mathrm{~b} / 4$

' amel işlerse baña baña getürür $\quad 25 \mathrm{~b} / 1$

\section{Cevherî fiil}

Tek başına hiçbir hareket ifadesi taşımaz; herhangi bir yapım ekiyle gövde halinde genişletilemez. Sadece kendisi olarak kullanılır (Güneş, 1999: 154). Eski Türkçede er- yardımcı fiilinin er- > ir- > ibiçiminde ekleşmesinden oluşan, ad soylu kelimelerin yüklem olarak kullanılmasını sağlayan ve birleşik fiil çekimlerinde görev alan fiil, cevher-fiil (ek-fiil)dir (Korkmaz, 2017: 124).

Cevherî fiilinin Eski Türkçeye ait metinlerde; görülen geçmiş zaman, öğrenilen geçmiş zaman, geniş zaman, gelecek zaman, şart kipi, emir kipi gibi çeşitli zaman ve kiplerle çekime girmiştir (Şahin, 2021: 23-24). er- fiili ile birleşik fiil çekimi (bkz. Birleşik Çekimler) oluşturulur.

Geniş zaman çekimi, 1. ve 2. kişi için müstakil kişi ekleri 3. kişi için ise tur- fiilinin geniş zamanından kalıplaşan $+\mathrm{dUr}$ (dUrUr) ve ol- fiilinin çekimi kullanılması bakımından diğer zamanlara göre farklılık göstermektedir.
Örnek:
kendü dahı eyüdür $28 \mathrm{~b} / 14$
içinde nesne yok $+\varnothing 26 \mathrm{~b} / 4$
maşrı̣dağı ben idüm 22b/7

\section{Sonuç}

1) XVIII. yüzyılda yazılmış olan Vesīe-nâme’nin tespit edilebilen tek nüshası Koç Üniversitesi Dijital Koleksiyonlar bölümünde bulunmaktadır.

2) Dinî ve didaktik bir eser olan Vesīle-nâme, dönemin konuşma diliyle yazılmış ve üslup açısından farklıllk ve zenginlik gösterir.

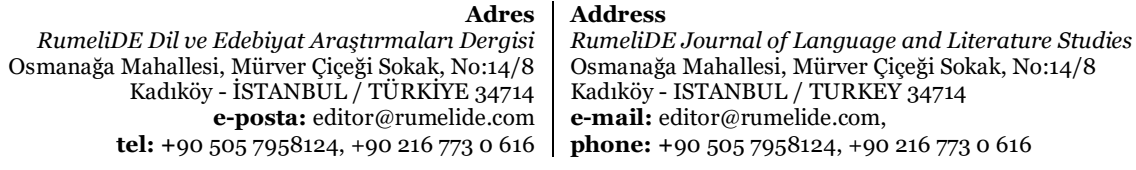


3) Metnin yazım (imla) özellikleri, yazıldı̆̆ı dönem göz önüne alınarak, burada genel itibariyle belirtilmiştir.

4) Ünsüz uyumunu bu dönemdeki Arap harfli metinlerde kelimelere yeni ekler getirildiğinde genellikle tonlu ünsüzler kullanıldı̆̆ından tespit etmek zordur.

5) Vesīe-nâme'nin ses bilgisi özelliklerinden damak ve dudak uyumu, yazıldığı dönem itibariyle, genellikle tamamlandığı görülmektedir. Ayrıca yuvarlaklaşma, düzleşme, yutulma, ötümlüleşme, ötümsüzleşme, erime, düşme gibi hadiselerin sadece örnekler üzerinden verilmeye çalışılmıştır.

6) Morfoloji bölümünde isim ve fiil çekimi işlenmiştir. Hâl eklerinin örnek kullanılışları tespit edilmeye çalışıldı. Zaman ve kip ekleri örneklerle açıklandı. Metinde geçen yapım ekleri de örneklerle verilmeye çalışıldı.

7) Vesile-nâme üzerindeki doktora tez çalışması tamamlandığında tarihi Türkiye Türkçesi alanında çalışanların, özellikle söz varlığı olmak üzere, dil özellikleri, dönemin kültürü ve konuşma dili hakkında sıkça faydalanacă̆ı bir çalışma olması umulmaktadır.

\section{Kaynakça}

Akar, A. (2005). Türk Dili Tarihi. İstanbul: Ötüken Neşriyat.

Aksan, D. (2015). Her Yönüyle Dil, Ana Çizgileriyle Dilbilim II. Ankara: TDK.

Aksan D. ve diğerleri (1976). Sözcük Türleri I-II. Ankara: TDK ya 1. C. 149. Ankara: TDK. (1983) 2. C., 2. baskı, Ankara: TDK.

Arat R. R. (Nisan 1955). “Türkçede Kelime ve Eklerin Yapısı”. Türk Dili Dil ve Edebiyat Dergisi, C: IV, S: 43 .

Aydın, E. (2019) Muḥammed bin Ḧüseyin Er-Revanînin Ḥilyet'ül-Mülûk Adlı Eseri (İnceleme-MetinDizin). (Doktora Tezi). Uludağ Üniversitesi, Bursa.

Banguoğlu, T. (2015). Türkçenin Grameri. Ankara: TDK.

Bilgegil, K. (2014). Türkçe Dilbilgisi. Erzurum: Salkımsöğüt.

Caferoğlu, A. (2001). Türk Dili Tarihi. İstanbul: Alfa.

Demir N. ve Yllmaz E. (2003). Türk Dili El Kitabı. Ankara: Grafiker.

Demir Y. ve Yllmaz E. (2002). “Osmanlı Türkçesi”, Türkler Ansiklopedisi, Cilt: 11.

Develi, H. (1995). XVII. Yüzyıl Osmanl Türkçesinde Ses Benzeşmeleri ve Uyumlar. Ankara: TDK.

Dizdaroğlu, H. (1963). Türkçe Fïller. Ankara: TDK.

Duman, M. (2004). "Eski Anadolu Türkçesi Dönemine Ait Bazı Metinlerdeki Dil Uyumuna Aykırı Örnekler Üzerine”. V. Uluslararası Türk Dili Kurultayı Bildirileri, c.1.

Eckmann, J. (2013). Çağatayca El Kitabı (Günay Karaağaç çev.). İstanbul: Kesit.

Ediskun, H. (2017). Yeni Türk Dilbilgisi. İstanbul: Remzi.

Emre, A. C. (1945). Türk Dil Bilgisi: Türkçenin Bugünkü ve Geçmişteki Gelişmeleri Üzerine Gramer Denemesi. Ankara: TDK.

Ercilasun, A. B. (2016). Türk Dili Tarihi. Ankara: Akçăg.

Gencan, T. N. (2001). Dilbilgisi. Ankara: TDK.

Gökçe, A. (2009) "Eski Anadolu Türkçesinden Osmanlı Türkçesine Dudak Uyumu ve Ünsüz Uyumu”. Turkish Studies. Volume 4/3 Spring.

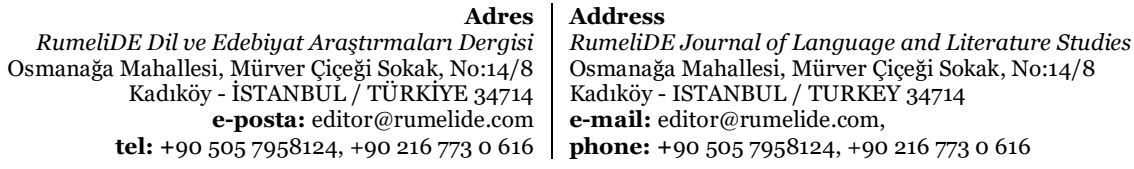


Gülsevin, G. ve Boz E. (2004). Eski Anadolu Türkçesi. Ankara: Gazi.

Gülsevin, G., (2004). "Türkçede Sıra Dışı Ekler ve Eklerin Tasnif-Tanımlanma Sorunu Üzerine”, 5. Uluşlararası Türk Dili Kurultayı, 20-26 Eylül. Ankara: TDK.

Gülsevin, G. (1997). “Türkiye Türkçesinde Zaman ve Kip Çekiminde Birleşik Yapılar Üzerine”, TDAYBelleten. Ankara: TDK.

Gülsevin, G. (2020). Eski Anadolu Türkçesinde Ekler. Ankara: TDK.

Gülsevin, S. (1999). “-DIK / (y)ACAK+İyelik Eki Yapılarının Öznelerinde İlgi Ekinin Kullanılması Üzerine”. Uluslararası Türkçe Edebiyat Kültür Eğitim Dergisi, 2015, S. 4/3.

Güneş, S. (2009). Türk Dili Bilgisi. İzmir: D. E. Ü. Matbaa.

Hatiboğlu, V. (1972). Dilbilgisi Terimleri Sözlüğü. Ankara: TDK.

Hengirmen, M. (2007). Türkçe Dilbilgisi. İzmir: Ergun.

Karaağaç, G. (2013). Dil Bilimi Terimleri Sözlüğü. Ankara: TDK.

Karabey T. ve Atalay M. (2017). Ahmet Cevdet Paşa Belâgât-ı Osmaniyye. Ankara: Akçă̆g.

Kartallıŏlu, Y. (2011). Klâsik Osmanlı Türkçesinde Eklerin Ses Düzeni (16, 17ve 18. Yüzyıllar). Ankara: TDK.

Koç, N. (1996). Yeni Dilbilgisi. İnkılâp Kitap Evi.

Korkmaz, Z. (2017). Dil Bilgisi Terimleri Sözlüğü. Ankara: TDK.

Korkmaz, Z. (2017). Türkiye Türkçesi Grameri Şekil Bilgisi. Ankara: TDK.

Savran, H. (2008/1). “Türk Dilinde ‘+DIr’ Bildirme Eki ve ‘+DIr’ Bildirme Ekiyle Yapılan Belirsizlik Kelimeleri”, U. Ü. Fen Edebiyat Fakültesi Sosyal Bilimler Dergisi, Yıl: 9, Sayı: 14.

Şahin, H. (2003). Eski Anadolu Türkçesi. Ankara: Akçağ.

Şahin, H. (1993). Farah-nâme (Dil Özellikleri-Metin-Söz Dizini). (Doktora Tezi), İnönü Üniversitesi: Malatya SBE.

Şahin, H. (2021). Türk Dili Üzerine Yazılar. Ankara: Akçă̆.

Topaloğlu, A. (1989). Dil Bilgisi Terimleri Sözlüğü. İstanbul: Ötüken Neşriyat.

Zülfikar, H. (1969). Yabancılar İçin Türkçe Dersleri. Ankara: AÜ Türkçe Kursu.

RumeliDE Dil ve Edebiyat Araştırmaları Dergisi Osmanağa Mahallesi, Mürver Çiçeği Sokak, No:14/8 Kadıköy - İSTANBUL / TÜRKIYE 34714 e-posta: editor@rumelide.com tel: +90 $5057958124,+902167730616$
Address

RumeliDE Journal of Language and Literature Studies Osmanağa Mahallesi, Mürver Çiçeği Sokak, No:14/8

Kadıköy - ISTANBUL / TURKEY 34714

e-mail: editor@rumelide.com,

phone: +90 5057958124, +90 2167730616 